\section{New distributional record of a rare sedge Kobresia (Cyperaceae) from Sikkim, India}

\author{
Bikash Jana ${ }^{1}$, R.C.Srivastava ${ }^{2}$, D.G. Long ${ }^{3}$ \& \\ G.P. Sinha ${ }^{4}$
}

${ }^{1,2}$ Botanical Survey of India, CGO Complex, DF Block, $5^{\text {th }}$ Floor, Sector I, Saltlake, Kolkata, West Bengal 700064, India ${ }^{3}$ Herbarium, Royal Botanic Garden, Edinburg | Inverleith Row, Edinburgh EH3 5LR, Scotland, UK

${ }^{4}$ Botanical Survey of India, Central Regional Centre, 10 Chatham Lines, Allahahabd, Uttar Pradesh 211002, India Email: ${ }^{2}$ rcs_bsi@yahoo.co.in (corresponding author),

${ }^{4}$ drgpsinha@gmail.com

Kobresia, a genus established by Willdenow in 1805 , is placed in the tribe Cariceae under the subfamily Cyperioideae of the sedge family Cyperaceae. The genus is characterized by its utricles, which are more or less open on one side and in having at least some bisexual spikelets with male flowers above the female flowers. There are about 65 species (Govaerts et al. 2007) distributed in the northern hemisphere, especially at high altitudes in the Himalaya, India, China and central Asia. About 42 taxa are recorded so far from India. It is one of the important genera in the alpine flora of the eastern and western Himalayan region of India. It is also an important pasture plant dominating a vast area of the alpine region where grazing animals feed extensively on it.

Date of publication (online): 26 June 2012

Date of publication (print): 26 June 2012

ISSN 0974-7907 (online) | 0974-7893 (print)

Editor: N.P. Balakrishnan

\section{Manuscript details:}

Ms \# 03039

Received 19 December 2011

Final received 16 May 2012

Finally accepted 30 May 2012

Citation: Jana B., R.C. Srivastava, D.G. Long \& G.P. Sinha (2012). New distributional record of a rare sedge Kobresia (Cyperaceae) from Sikkim India. Journal of Threatened Taxa 4(6): 2664-2666.

Copyright: () Bikash Jana, R.C. Srivastava, D.G. Long \& G.P. Sinha 2012. Creative Commons Attribution 3.0 Unported License. JoTT allows unrestricted use of this article in any medium for non-profit purposes, reproduction and distribution by providing adequate credit to the authors and the source of publication.

Acknowledgements: Authors are grateful to the Director, Botanical Survey of India for facilities.

\section{OPEN ACCESS | FREE DOWNLOAD}

While revising the genus Kobresia Willd. (Cyperaceae) in India under 'Flora of India Project' of the Botanical Survey of India, the authors came across specimens in the BSHC herbarium, which on critical studies were identified as $K$. harae Rajbh. \& H. Ohba. A scrutiny of the literature (Clarke 1894; Karthikeyan et al. 1989; Kuekenthal 1909; Koyama 1978; Noltie 1994; Noltie \& Zhang 2010) and herbaria revealed that this species is known so far from Nepal only. Therefore, the present collection from northern Sikkim forms the first report for India.

\section{Kobresia harae Rajbh. \& H. Ohba in J. Jap. Bot. 62(7): 193, f.1. 1987.} (Image 1)

Type: Nepal: Janakpur Zone, Ramechhap District, Serdingma-Dubikharka, 3400-3720 m, 7.vii.1985, Ohba et al. No.8570278 Holotype (TI)

Specimen examined: 13.vii.1996, 3520m, Yumthang, North Sikkim District, Sikkim, India, coll. G.P. Sinha \& D.G. Long, 17821 (BSHC) (Image 2).

Perennial herbs. Rhizome elongated, ca. 4 × $0.3 \mathrm{~cm}$ covered with brownish-black scales. Culms slender, erect, 9.5-10.1 cm x $0.5 \mathrm{~mm}$, triquetrous, smooth; base covered with brownish-black lamina bearing outer sheaths. Leaves ca. 2-7 cm x 1.5-2 mm, much shorter than the culm; lamina linear, slightly scabrid at apex, midrib smooth, greenish in colour; sheath 1-2 cm long. Inflorescence erect, racemose, oblong, ca. $2.4 \mathrm{~cm} \mathrm{x}$ $1 \mathrm{~mm}$ with 4-6 spikes; axis slightly triquetrous. Spikes oblong, 9-11 x 3mm, with about 5 or 6 spikelets. Spikelets all unisexual, lowest and lateral ones female and terminal one male. Glumes of the lowest spikes broadly ovate, ca 4x1 mm, glabrous, brownish, margin slightly hyaline, prominently, 1-nerved, apex long attenuate, scabrid, base slightly sheathing. Lowest spikelets female, elliptic, ca. 4 x $0.75 \mathrm{~mm}$. Glumes of the female spikelets ovate to ovate-elliptic, ca. 2.5 x $0.5 \mathrm{~mm}$, apex slightly acute to obtuse, glabrous, brown, margin slightly hyaline at apex. Prophyll linear to oblanceolate, ca. 4 x $0.75 \mathrm{~mm}$, membranous, smooth, brownish, upper portion hyaline, margin

BSHC - Botanical Survey of India Sikkim Himalayas Circle Herbarium 

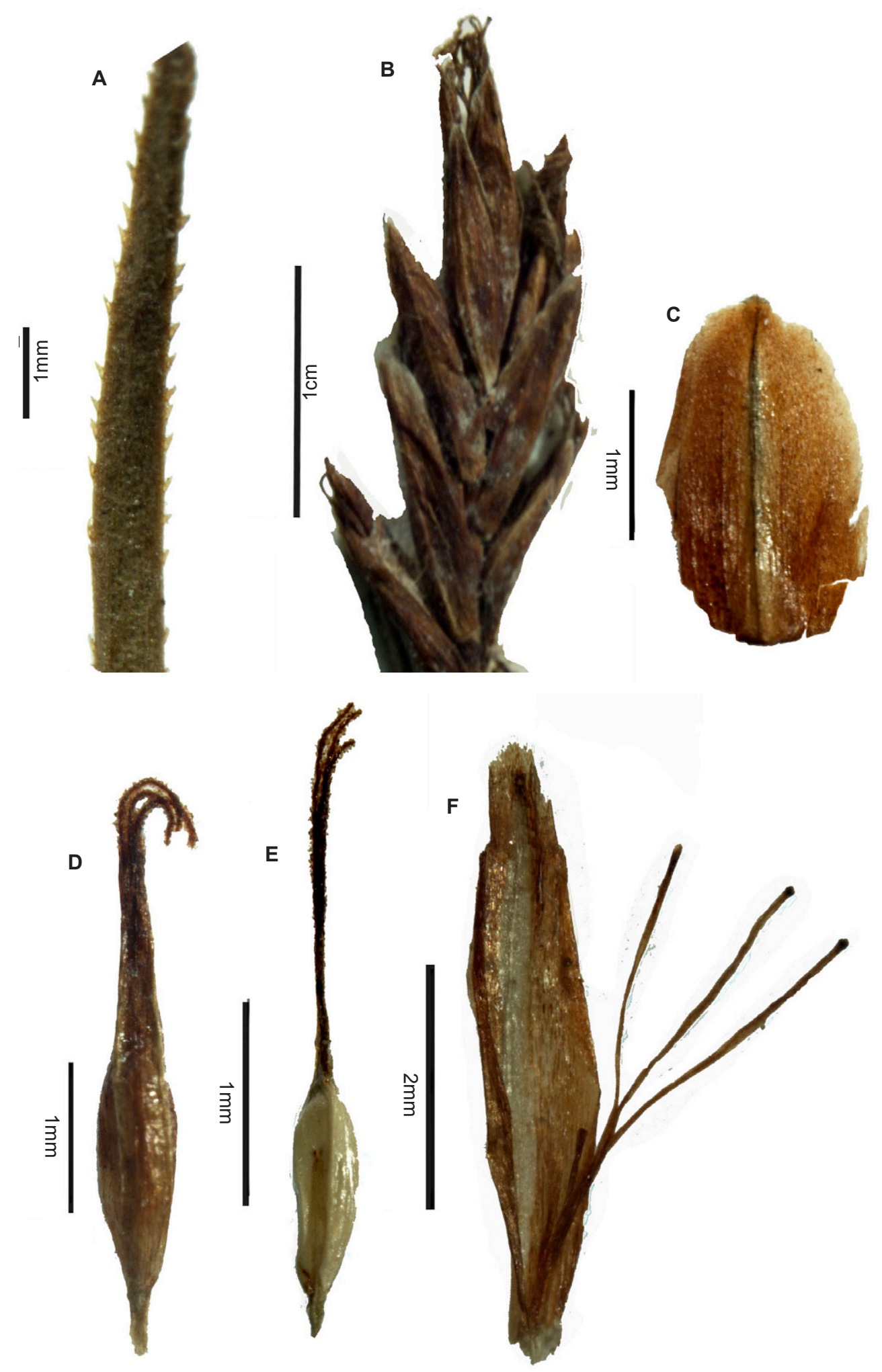

Image 1. Kobresia harae Rajbh. \& H. Ohba

A - close-up of apical portion of leaf; B - apical portion of inflorescence; C - female glume; D - prophyll with gynoecium; E - gynoecium; F - Male spikelet. 


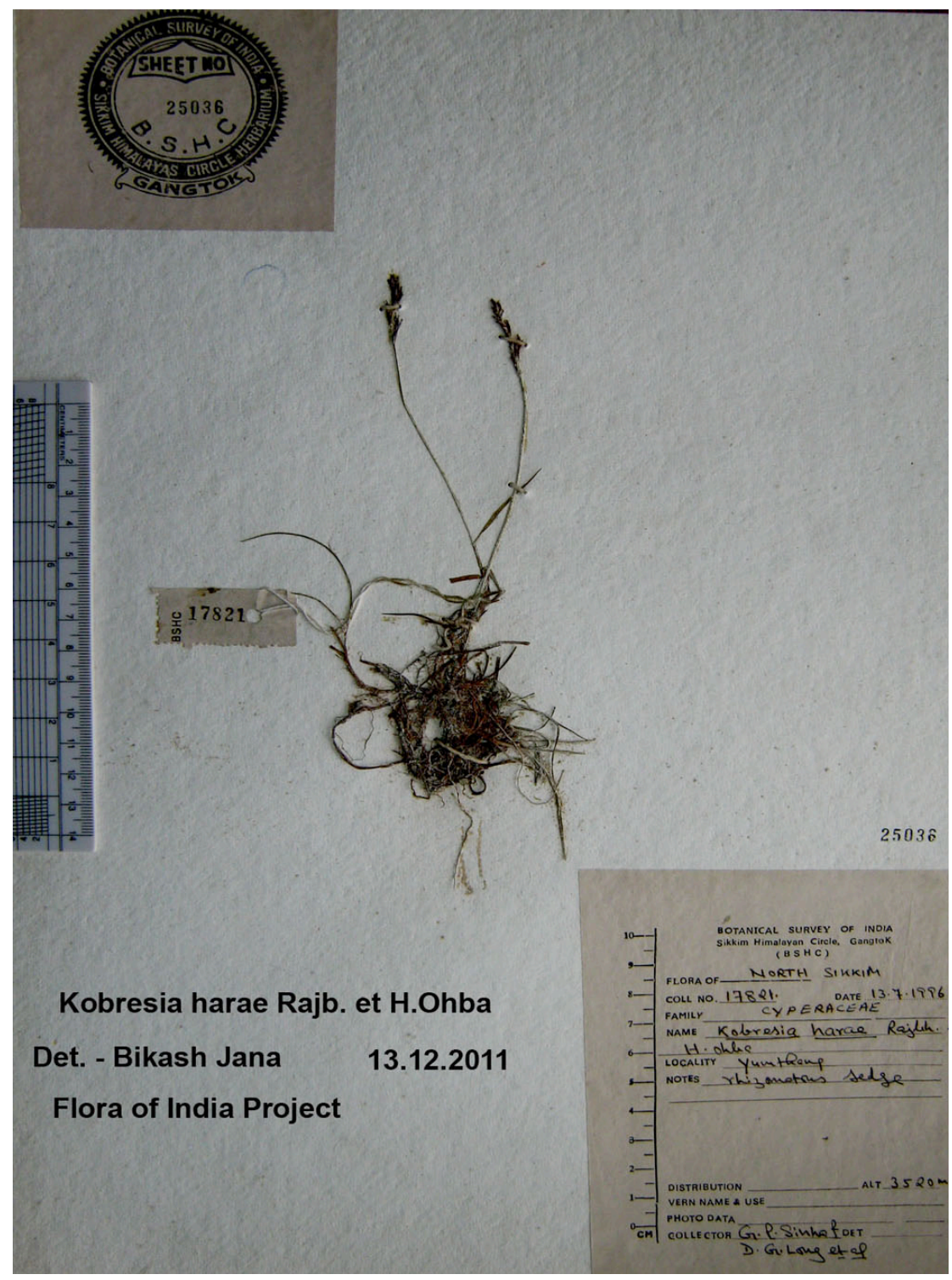

Image 2. Herbarium of Kobresia harae

open in upper half from apex to the middle. Male glume broadly elliptic-lanceolate, ca. 5 x $0.5 \mathrm{~mm}$, apex obtuse, glabrous. Stamens 3; filaments slender. Gynoecium ca. 3 x 0.5 mm; style 3-fid, ca.1mm long; ovary trigonous, obovate, ca 2 × $0.5 \mathrm{~mm}$, smooth, light yellow in colour. Rachiola $3 / 4^{\text {th }}$ of the ovary, 1 -nerved, smooth, greenish-yellow in colour.

Flowering and Fruting: July.

Distribution: India: Sikkim ( Yumthang); Nepal.

\section{REFERENCES}

Clarke, C.B. (1894). Kobresia Willd. 6: 696-702. In: Hooker, J.D. (ed.). Flora of British India. L. Reeve, London.

Govaerts, H.A. Rafael \& D. Simpson (2007). World Checklist of Cyperaceae:Sedges. Royal Botanic Garden, Kew.

Karthikeyan, S., S.K. Jain, M.P. Nayar, M. Sanjappa (1989). Florae Indicae Enum. Monocot. Botanical Survey of India, Calcutta, 58-60pp.

Koyama, T. (1978). Kobresia, pp. 112-114. In: Hara, H., W.T. Stern \& L.H.J. Williams (eds.). An Enumeration of The Flowering Plants of Nepal-Vol. 1. British Museum (Natural History), London.

Kuekenthal, G. (1909). Kobresia Willd. In: Engler, Pflanzenr. Heft 38: 40-48. Berlin.

Noltie, H. J. (1994). Kobresia Willdenow, 1(3): 333-352. In: Grierson \& Long (eds.). Flora of Bhutan. Royal Botanic Garden, Edinburgh.

Noltie, H.J. \& S.R. Zhang (2010). Kobresia Willd., pp. 23: 269-285. In: Flora of China - Cyperaceae. Missouri Botanical Garden Press (St. Louis), USA. 